\title{
ALQUIMIA VERBAL Y EXISTENCIAL EN LA POESIA DE CECILIA BUSTAMANTE
}

\author{
POR \\ RAMON LAYERA \\ University of Texas
}

Comenzando con el Inca Garcilaso de la Vega, la historia intelectual y literaria del Perú ha sido siempre patrimonio exclusivo de los hombres. Para encontrar autoras que pretendan alcanzar el nivel de Alfonsina Storni, Juana de Ibarbourou, Delmira Agustini o Gabriela Mistral en la literatura hispanoamericana hay que ir a otras latitudes y otras sociedades y culturas donde la mujer haya tenido una participación más activa en el quehacer literario y en la vida nacional. En el panorama literario e intelectual peruano las mujeres brillan por su ausencia y las excepciones son honrosas y contadas. Librarse decididamente del modelo arquetípico de la limeña colonial concupiscente, frívola e intrigante ha sido para ellas, sin duda, una primera tarea. De entre muchas autoras menos conocidas que intentaron oponer su espíritu creador e inteligencia al «perricholismo» esperado de ellas, sólo se nos da noticia de la novelista Clorinda Matto de Turner, cuya labor en beneficio de los indígenas del campo peruano encontró expresión artística en su novela Aves sin nido (1889). El caso más reciente es el de la poetisa Cecilia Bustamante, hasta ahora la única mujer que ha recibido el Premio Nacional de Poesía en el Perú.

Altamente sintomático de un aparente descuido de la crítica por la producción literaria de esta distinguida poetisa peruana es quizá el hecho de que, con la excepción de algunos breves y poco enjundiosos comentarios sueltos en los suplementos dominicales de algunos periódicos limeños, no haya aparecido aún ningún análisis sistemático de su obra. Significativa omisión en el caso de una obra poética de más de veinte años que había cuajado en varios libros y que había merecido tres veces la primera mención honrosa en certámenes nacionales de poesía antes de obtener el Premio Nacional en 1965.

La producción poética de Cecilia Bustamante comienza en 1956, en 
revistas limeñas, e incluye la colección de poemas Altas hojas, publicada en Lima en 1961 con un prólogo de Juana de Ibarbourou, y Símbolos del corazón, también de 1961. En 1963 apareció en Lima Poesía, un compendio de su labor creadora a la fecha. Nuevos poemas y Audiencia, el libro de poemas que obtuvo la distinción del Premio Nacional, fue publicado en Lima en 1964. Su libro más reciente, El nombre de las cosas, apareció en Montevideo en 1970 y ha sido reeditado en El Salvador en 1979. Este mismo año apareció Amor en Lima, una breve selección del texto poético Discernimiento, que está ahora en prensa '. E1 interés que ha despertado su poesía en el extranjero se refleja en varias traducciones de su poesía al inglés, francés y flamenco, que han aparecido en revistas y antologías de Europa y los Estados Unidos ${ }^{2}$.

Desde los primeros poemas hasta los más recientes la voz poética de Cecilia Bustamante se ha definido con singular originalidad. Sus temas, símbolos e imágenes conforman un estilo inconfundible en el que se puede distinguir la economía verbal, la percepción insólita y la necesidad de comunicar una verdad duradera. Al igual que su compatriota César Vallejo, que también tuvo que deshacerse de algunos resabios posmodernistas, Cecilia Bustamante se libra bien temprano del clisé y la afectación sentimental y se lanza en búsqueda de un estilo auténticamente definitorio. Ya en los primeros poemas de la colección «Aquí es la tierra» se vislumbra el deseo de comunicar, aunque con parquedad, los

${ }^{1}$ Los datos de publicación de las obras de Cecilia Bustamante son los siguientes: Tres poetas: Cecilia Bustamante, Jorge Bacacorzo, Arturo Corcuera. Presentación de Ernesto More (Lima: Ediciones Pro-Hombre, 1956); Altas hojas. Prólogo de Juana de Ibarbourou y colofón de Luis Alberto Sánchez (Lima: Ediciones de la Dirección de Cultura del Ministerio de Educación Pública, 1956); Símbolos del corazón. Nota de Antenor Orrego (Lima: Ediciones de la Escuela Nacional de Bellas Artes, Colección Forma y Poesía, 1961); Poesía (Lima: Ediciones Flora, Talleres Gráficos P. L. Villanueva, 1963); Nuevos poemas y Audiencia (Lima: Ediciones Flora, Talleres Gráficos P. L. Villanueva, 1965); El nombre de las cosas (Montevideo: Editorial Alfa, Colección Carabela, 1970); 2. ${ }^{a}$ edición (San Salvador: Editorial Cuscatlán, 1978); Amor en Lima (Lima: Ediciones de «La manzana mordida», 1977); Discernimiento (México: Premiá Editora, S. A., 1979, en prensa). Todas las citas y referencias incluidas en este artículo corresponden a estas obras $\mathrm{y}$ ediciones.

2. En Peru: The New Poetry, ed. and trans. David Tipton (New York: Red Dust, 1978); Convergence/Convergencia, trans. Miriam Joel, ed. Julio Ramos (Austin, 1978); el poeta belga Marcel Hennart ha traducido El nombre de las cosas al francés y una selección de poemas al flamenco; Maureen Ahern (Arizona S. U.) revisa ahora su traducción al inglés de la misma obra, y la poetisa Mary Crow prepara una selección de poemas de C. Bustamante en traducción inglesa para una antología que publicará la Columbia University Press. 
enigmas indescifrables de la existencia. Cada poema constituye una síntesis apretada de pasión y pensamiento, de calculado y sugerente hermetismo. Nos invita a presenciar el rito eterno e invariable de la vida en esta tierra y acepta, en el primer poema, la presencia simultánea e ineludible del «llanto» y la «inefable alegría». Para crédito de la autora, el lirismo panteísta de los poemas que siguen no cae en una vana complacencia esteticista. Por el contrario, la poetisa, al hundir su visión «en este inmenso mundo» para que germine «su sangre» y florezca su entendimiento, inicia un lento y tortuoso viaje, a veces íntimo, a veces cósmico, hacia el centro de las cosas. En esta búsqueda de ese «idioma esperado que desanude este mundo dentro» del poeta hay implícitas más preguntas que respuestas. La impresión cumulativa que deja esta primera colección es la de una poesía no declarativa, de mensajes crípticos y de sugerencias veladas.

El mismo estado de permanente asombro y lucidez de la primera colección se observa también en Altas hojas, el segundo libro de poemas. Sólo que aquí ya se profundiza la observación minuciosa de los signos y los detalles de la experiencia humana. También se hace más sistemático el análisis del tiempo, «múltiple y único», como tránsito impostergable. La visión de la muerte, recurrente y, a veces, obsesiva en el resto de su obra, se expresa con una perspectiva que no excluye el optimismo implícito en la necesidad de perdurar. Para la poetisa, el ser humano, "como los astros que coronan el espacio», tiene su propia eternidad. Su existencia individual y la de «los hombres de todos los tiempos» se prolonga con la solidaridad de la muerte y está

En el fondo de todas las cosas,
intermitente y sin descanso
.......................................
y su polvo ennoblece los embriones de las plantas.

(Altas hojas, VIII)

El anhelo y la búsqueda de la permanencia son expresados en formas diversas. Por encima de todo, se rechaza el transcurso del tiempo como un devenir estéril; en cambio, se acepta como un proceso regenerativo de descomposición y crecimiento en el que reside la fuente de la existencia.

Instalada en el centro de esta preocupación por la muerte, la soledad y el paso del tiempo, se encuentra la necesidad vital de comunicar la emoción y el sentimiento. De todos, el amor es el paliativo esencial que nos redime, 
... aunque nos abata la soledad

y la tranquilidad voraz del tiempo.

(Altas hojas, XVI)

En el poema XVII, la expresión máxima del amor en su dimensión física refleja nítidamente la virtud alquímica de la poesía de Cecilia Bustamante. En este poema el amor sensorial y espiritual se amalgaman en una síntesis apretada de imágenes y signos en la que el amor es la «palabra en el cuerpo». La experiencia erótica, igual que en la poesía de John Donne, trasciende los límites seculares de la carne y alcanza un plano metafísico. El proporcionado equilibrio del amor aparece concentrado verbalmente en una fórmula poética que opone la ternura y la luz frente a la profundidad de la pasión y la oscuridad de la sangre.

Los poemas que siguen también ilustran las propiedades alquímicas de esta primera poesía. En el poema XX hay una enumeración lírica de las fórmulas ideales recomendadas para «matar el germen frío de la soledad». El poema XXI revela la voluntad horaciana del poeta que intenta resumir y retener el flujo natural e inexorable del tiempo actuando sobre las gentes y las cosas. Más adelante, en un raro paréntesis autobiográfico, aparece un testimonio de la influencia paterna y materna en la sensibilidad y los atributos de la poetisa. El último poema es un viaje a la nostalgia que completa el ciclo poético con un retorno al santuario del amor maternal.

El poemario «Símbolos del corazón» marca un cambio en el desarrollo poético de Cecilia Bustamante. Aunque todavía persiste el lirismo en las imágenes y la inexorabilidad del tiempo como tema central, estos nuevos poemas incorporan el desamparo, la amargura y el desencanto. En el segundo poema se nos advierte ya que «aunque el poeta sueñe» y «calle», «la herida es dolorosa». E1 temido avance hacia la muerte trae presagios de mayor soledad:

\author{
porque en la soledad de las edades \\ los hombres son \\ como caducas semillas \\ que alimentan las sombras. \\ («Símbolos del corazón», 3)
}

En los tres últimos poemas se unen los dos ámbitos poéticos de esta etapa de transición. El poema 10 incorpora un elemento nuevo en la exploración de la realidad al presentar el mar y los «caracoles muertos / presos en su movimiento inextinguible». Además de la fuerza y la inmensidad del mar, el poema alude a la eternidad de la naturaleza, que con- 
tinúa su movimiento perpetuo, arrastrando aun a los ya muertos. La vastedad del mar prefigura la búsqueda de un espacio verbal y existencial más amplio que se ha de dar en la poesía venidera. Por otra parte, y a guisa de despedida, los dos últimos poemas, «El lugar en la hierba» y el poema 12, vuelven al intimismo contemplativo de la poesía del período inicial. Aquí la poetisa habla de los padres ausentes, de la muerte individual y del mundo apacible, aunque vigilante y creativo, de los sueños.

El progresivo avance hacia una poesía menos realista y simple se hace evidente en «Heredad del amor», un poemario fechado en 1961. Las imágenes han perdido su diafanidad y han entrado al terreno ingrato de una realidad hostil. La visión bucólica y esperanzada de la poetisa en su primera juventud ha dado cabida a las preocupaciones seculares del mundo moderno, de los dramas de la pobreza y de la realidad contingente.

Con el nacimiento del hijo, la mujer poeta comienza a modular un «canto amable y solitario / aprendido en... hondas vigilias terrenales». En cambio, el mundo se ha tornado un «campo estéril de ubres apagadas, 'de pobres' a la intemperie». Ya en sus juegos el niño se ha plegado a la milicia de "gentes hoscas» que se odian «enseñando su estandarte y sus tambores». Aun «los recién casados», en el fugaz y feliz «temblor alucinado» del «instante», deben temer la inminente «sonrisa triste / o la palabra dura» que les espera mañana.

Los demás poemas de esta colección ahondan aún más esta visión desolada, amarga y de incontenible vergüenza ante el hambre. E1 dolor ajeno, la desesperanza y el desamor siguen fielmente el canon vallejeano, aunque con un lenguaje más escueto y directo. El último poema, sin embargo, constituye un sorpresivo cambio de expresión y tono en el que la hija, «la niña rezagada», se transforma en la protagonista de una escena pastoral de esperanza y certidumbre.

El poemario «El retorno», del año 1962, continúa este breve interludio. Una vez más la poetisa vuelve a utilizar esa peculiar mezcla de materia poética y realidad cotidiana y científica que caracterizó la poesía de John Donne ${ }^{3}$. Al igual que el poeta metafísico inglés, en el primer poema, "El astronauta», nos da un compuesto alquímico que sintetiza el amor y la ciencia, mientras que en el segundo poema nos pinta un bravo

${ }^{3}$ Para una comprensión cabal de este recurso poético véanse los ensayos de Samuel Johnson, sir Herbert Grierson y T. S. Eliot acerca de John Donne y los llamados «poetas metafísicos» en A. L. Clements, ed., John Donne's Poetry (New York: W. W. Norton, 1966), pp. 106-109, 112-130. 
nuevo mundo donde el mar será «agua dulce algún día» ${ }^{4}$. La visión alucinada de un mundo mejor desemboca finalmente en un "retorno» a esa vulgar realidad en que el "mundo feliz» de antes es ahora "un perro sucio» cuya «sangre envenenada / no (deja) crecer las flores».

Esta desazón aparente, acompañada de un sistema verbal cada vez más discreto, se hace más obvia en Nuevos poemas y Audiencia, sólo que ahora como manifestación de un impulso calculado y metódico. La poetisa ha alcanzado su madurez expresiva e intenta ir más allá de las superficies y alcanzar la esencia de las cosas.

La nueva etapa de desarrollo empieza, sin embargo, con ensayos y tentativas formales en las que a veces intenta el paso del símil a la metáfora pura; en otros casos se experimenta con imágenes de corte clásico. Por ejemplo, en «Dos mariposas» se configura una forma emblemática del amor en la que las amantes mariposas se cierran en sí mismas en un gesto eterno de entrega y muerte. En «Dos almejas» se nos ofrece un juego posmodernista, con sonidos y efectos sinestésicos. Pero esta experimentación no es gratuita y efectivamente abre los cauces naturales de expresión poética que ensaya la autora.

La etapa última muestra un tipo de poesía pura que distingue la voz poética de Cecilia Bustamante. El suyo es un estilo de poetizar antirrealista que dibuja un mundo estático, en que se suspende el momento, se congela la acción para descifrar los procesos y encontrar la esencia poética. Un ejemplo concreto de esto se observa en el poema «En la blanca trastienda». Es un poema sin acción, sin progresión narrativa, en el que la última estrofa es una enumeración de adjetivos que definen el ocio y la muerte implícita en él. Como éste, hay varios poemas en que cada imagen, cada situación, tiende a borrar la superficie tangible de la realidad para crear un mundo de belleza y significado elemental.

El grupo de poemas publicado bajo el subtítulo de Audiencia es un todo poético autónomo sostenido por la preocupación social de la poetisa. Del hermetismo característico pasamos aquí a un ejercicio de libre ironía en que se enjuician los oficios, las rutinas y las conductas ordinarias de la vida moderna. El poema más revelador es «Declaración de la madre», en el que Cecilia Bustamante nos muestra la doble virtud alquímica de ser mujer y poeta. Con aguda ironía, la poetisa pinta un

\footnotetext{
4 No debe extrañar el uso de formas poéticas «metafísicas» en una poetisa que lee y traduce poesía inglesa y norteamericana. Tiene en preparación colecciones de poesía de varios poetas ingleses y norteamericanos en traducción al español. Está por aparecer su traducción de la poesía de Silvia Plath en edición bilingüe en la Serie Moderna del Departamento de Humanidades de la Universidad Nacional Autónoma de México.
} 
cuadro alienante de la mujer víctima de la domesticidad y la sujeción a la tiranía diaria de las máquinas y utensilios caseros.

El juicio crítico y amargo de Audiencia se cierra con un cuadro analítico de las posibilidades múltiples del arte. La autora se define aquí por el tipo de artista «extraño» que se remonta a las intuiciones y que considera el arte como «una verdadera aventura en el caos». Esta aventura garantiza a la exploración creativa una existencia independiente y perdurable.

El último libro de poemas, El nombre de las cosas, publicado en 1970 , continúa esta tarea de exploración poética, aunque esta vez a niveles de creciente hermetismo y economía verbal. La palabra y la imagen han quedado desprovistas de acción y actúan en la sensibilidad a través de la alusión sugestiva, de la evocación constante. E1 poema «Botánica», por ejemplo, es un cuadro de permanencia estática desprovisto absolutamente de formas verbales. En este nuevo universo poético los puntos de referencia son menos evidentes, aunque el poder de sugerencia se ha acentuado. La poetisa ha dejado atrás el objeto mismo para concentrarse, a través de un proceso de elipsis y síntesis, en la capacidad individual del sujeto de experimentar y comunicar la emoción poética. Ocasionalmente aparece un correlato objetivo fácilmente discernible; en «Internado" vemos a la niñez oprimida y en "Matrimonio civil» las gesticulaciones rituales de una burguesía engominada y pulcra. Pero éstas son excepciones realistas menores en un lenguaje y una visión definitivamente más cerca de la fantasía y la abstracción.

Al entrar en una compleja etapa de madurez poética, Cecilia Bustamante continúa el trabajo riguroso y variado que le es característico. Su labor artística no ha caído en una poesía frívola o de invectivas y ensimismamiento. Su obra es una poesía de revelación e intento de salvación del individuo atrapado en el absurdo de la vida, la inexorabilidad det tiempo y el avance hacia la muerte. El ojo alerta e insomne de su percepción poética escudriña y desnuda la esencia de los hechos y las cosas para expresar su significado. Su mensaje profundo se nutre de la más transida y fraternal humanidad. Sin duda, este nuevo período promete más revelaciones y logros poéticos en una carrera ya consagrada. 
